ACTA MYCOLOGICA

Vol. 42 (2): 239-244

2007
Dedicated to Professor Alina Skirgietto

on the occasion of her ninety-fifth birthday

\title{
Soil fungi communities from young Scots pine plantations affected with root rot
}

\author{
WOJCIECH SZEWCZYK
}

\author{
Department of Forest Pathology, Agricultural University \\ Wojska Polskiego 71c, PL-60-625 Poznań,wszew@au.poznan.pl
}

S z e w c zy k W.: Soil fungi communities from young Scots pine plantations affected with root rot. Acta Mycol. 42 (2):239-244, 2007.

The aim of work was to investigate the qualitative and quantitative characteristic features of soil fungi associations occurring in I class pine stands threatened by pathogens of tree roots in Zielonka Experimental Forest District (W Poland). During the mycological analyses of soil, a total of 694 isolates of fungi representing 33 species were obtained. The most numerously represented species was Penicillium daleae which made $75 \%$ of all isolates. The second place in the ranking belonged to Penicillium janczewski amounting to $11 \%$. In order to define the qualitative and quantitative similarity between the studies areas, a proportional inconformity was determined. The greatest similarity occurred between the associations of soil fungi obtained from site $64 \mathrm{c}$ and $35 \mathrm{~b}$.

Key words: soil fungi, Scots pine, plantations

\section{INTRODUCTION}

Fungi occur in all environments; they play an important role, both a positive and negative one, in the life of other organisms and ecosystems. Soil environment is very favorable for fungi, they participate in the decomposition of dead organic matter, particularly in conditions of a low $\mathrm{pH}$ level which limits the activity of bacteria, and they enter into mycorhizal relations with trees. There is no doubt that there exist many factors affecting the quality of relations dominating in the soil determining thereby the occurrence of the particular species of organisms or whole organism associations. Associations of organisms occurring on a given area together with arbores cent species decide about the quality of ecological factors in the given place reacting to all changes taking place there (Mań ka 1974). Therefore, it is important to get familiar with the biodiversity of these associations (Kowalski 1996) which can decide about the health of plants (Dahm, Strzelczyk 1977). The objective of the present study was to investigate the qualitative and quantitative characteristic 
features of soil fungi associations occurring in I class pine stands threatened by pathogens of tree roots.

\section{MATERIALS AND METHODS}

Studies were carried aut in seven separated sites (Tab. 1) localized in I class pine stands of the Experimental Forest District Zielonka (W Poland).

In each separated site, soil samples were taken from one studied area in order to isolate fungi communities. Soil for mycological analyses was taken from the depth of $5-20 \mathrm{~cm}$ from 6 sites uniformly distributed on a circle with an about $6 \mathrm{~m}$ radius. The obtained 6 samples were mixed, givining in this way a sample of about $1 \mathrm{dm}^{3}$ volume. Fungi were isolated using Warcup's method (Warcup 1950) in the modification of K. Mańka (Jensen, Mańka 1961; Mańka, Salmonowicz 1987). From each flask containing soil and sand, 10 Petri dishes were prepared. In this way, the mycological soil analysis from one area was based on 30 Petri dishes. Incubation was carried out for 7 days at room temperature. After this period, the first colonies of fungi which developed on Petri dishes were separated. Fungi separation was repeated after 3 successive days. The developed fungi colonies were transferred to test-tubes with agar-glucose-potato nutrients. After 2-3 weeks of incubation, the separated isolates were described. The description included the dish number from which the colony of fungi was separated and the successive number of test-tube. Then, the developed mycelia were compared and groups with the same macroscopic features were separated. After 2 weeks, the representatives of these particular groups were transferred to Petri dishes with agar-glucose-potato nutrient. After 10 days of incubation, the fungi were identified and described. In this way, soil fungi associations obtained and systematized.

Table 1

Characteristic and location investigation area

\begin{tabular}{|c|c|c|c|}
\hline Compartment & Forest Range & Forest site type & Pine age in 2002 \\
\hline $47 \mathrm{k}$ & Huta Pusta & $\begin{array}{c}\text { Fresh mixed coniferous } \\
\text { forest }\end{array}$ & 9 \\
\hline $43 \mathrm{f}$ & Kamińsko & Fresh coniferous forest & 12 \\
\hline $64 \mathrm{c}$ & Kamińsko & $\begin{array}{c}\text { Fresh mixed } \\
\text { broadleaved forest }\end{array}$ & 10 \\
\hline $85 \mathrm{c}$ & Potasze & $\begin{array}{c}\text { Fresh mixed coniferous } \\
\text { forest }\end{array}$ & 9 \\
\hline $35 \mathrm{~b}$ & Huta Pusta & Fresh coniferous forest & 13 \\
\hline $5 \mathrm{a}$ & Rakownia & $\begin{array}{c}\text { Fresh mixed } \\
\text { broadleaved forest }\end{array}$ & 13 \\
\hline $142 \mathrm{~d}$ & Stęszewko & $\begin{array}{c}\text { Fresh mixed coniferous } \\
\text { forest }\end{array}$ & 13 \\
\hline
\end{tabular}


In order to determine the qualitative and quantitative similarities of the soil fungi communities obtained from the studied areas, on the basis of the number of common and different species, the formula of Marczewski-Steinhaus (Romaniszyn 1972; Leśniak 1984; Sierota 1995; Kowalski 1996; Tyszkiewicz 2001) was applied.

$$
S_{(1,2)}=\frac{w}{a+b-w}
$$

where:

$\mathrm{S}$ - similarity of two mutually comparable soil fungi communities

a - number of isolates of fungi communities 1 ,

$\mathrm{b}-$ number of isolates of fungi communities 2 ,

$\mathrm{w}-$ number of fungi association isolates common for both associations (1 and 2).

It is assumed that if the comparable communities have all features in common, the similarity is $\mathrm{S}=1$ or $100 \%$. If the studied communities have no common features, then their similarity is $\mathrm{S}=0$. Also the so called distance between the communities was determined: the more features are common, the smaller is the distance, and the less features are common, the greater is the distance. The distance of two associations $(\mathrm{r})$ is expressed by the formula:

$$
\mathrm{r}=1-\mathrm{S}
$$

Because of the discrete character of the data, in order to define the qualitative and quantitative similarity between the studies areas, a proportional inconformity was determined. The distance between the areas has been illustrated on dendrograms using the method of mean connections (Dobosz 2001).

\section{RESULTS}

During the mycological analyses of soil, a total of 694 isolates of fungi representing 33 species were obtained. The most numerously represented species was Penicillium daleae which made $75 \%$ of all isolates and it was present in all associations from all studied sites. The second place in the ranking belonged to Penicillium janczewski amounting to $11 \%$ and it was also present in all the studied associations except for the association from site 47k. The successive rank belonged to Chrysosporium merdarium (7\%), Ch. pannorum (7\%) and Penicillium stecki (4\%). Species group which occurred sporadically, they were represented by one isolate only, included: Mortierella isabelina, M. microspora var. macrocystis and two non-sporiferous species.

The most numerous soil fungi association was obtained from site $85 \mathrm{c}$, it consisted of 179 isolates representing 13 species. The least numerous was the community of soil fungi from site $47 \mathrm{k}$ including 63 isolates represented by 10 species. The poorest community regarding its qualitative aspect was the association from site $35 \mathrm{~b}$ represented by 9 species of soil fungi.

Table 2 contains the qualitative and quantitative composition of soil fungi associations from the particular studied areas. 
Table 2

Species of fungi obtained on investigation areas

\begin{tabular}{|l|c|c|c|c|c|c|c|c|}
\hline \multirow{2}{*}{ Species } & \multicolumn{7}{|c|}{ Area } & Total \\
\cline { 2 - 8 } & $5 \mathrm{a}$ & $35 \mathrm{~b}$ & $43 \mathrm{f}$ & $47 \mathrm{k}$ & $64 \mathrm{c}$ & $85 \mathrm{c}$ & $142 \mathrm{~d}$ & \\
\hline Absidia glauca Hagem & & & 2 & & & & 1 & 3 \\
\hline Acremonium charticola (J. Lindau) W. Gams & & & & 2 & & & & 2 \\
\hline Acremonium killiense Grütz & 3 & & & 1 & & & & 4 \\
\hline Acremonium pteridii W. Gams et Frankland & & & & & & 2 & & 2 \\
\hline Acremonium strictum W. Gams & & 1 & & 2 & & & 1 & 4 \\
\hline Alternaria alternata (Fr.) Keissl. & & & 4 & & & 1 & & 5 \\
\hline Aspergillus clavatus Desm. & 4 & & & 2 & & & & 6 \\
\hline $\begin{array}{l}\text { Chaetomium globosum Kunze (Ehrenb.) } \\
\text { J.W. Carmich }\end{array}$ & & & 3 & & & & & 3 \\
\hline Chrysosporium merdarium (Ehrenb.) J. W. Carmich & & 1 & & & & 32 & 15 & 48 \\
\hline Geomyces pannorum Sigleret J. W. Carmich & 10 & & 9 & & 3 & 25 & & 47 \\
\hline Mortierella isabellina (Oudem.) Arx & & & & & & & 1 & 1 \\
\hline Mortierella macrocystis (W.Gams) & & & & & & 1 & & 1 \\
\hline Umbelopsis nana (Linnem.) Arx & & & 2 & & & & & 2 \\
\hline Mortierella vinacea Dixon-Steward & 3 & & & & & & 2 & 5 \\
\hline Non-sporiferous 1 & & & & & & 1 & & 1 \\
\hline Non-sporiferous 2 & 2 & & & & & & & 2 \\
\hline Non-sporiferous 3 & & & & & & 8 & & 8 \\
\hline Non-sporiferous 4 & & & 1 & & & & & 1 \\
\hline Penicillium adametzii Zaleski & 3 & & & 5 & & & 2 & \\
\hline Penicillium citrinum Thom & & 9 & & 2 & 13 & 9 & 11 & 44 \\
\hline Penicillium daleae Zaleski & 52 & 69 & 40 & 46 & 39 & 74 & 36 & 356 \\
\hline Penicillium glabrum (Wenmer) Westling & & & & & & 6 & 1 & 7 \\
\hline Penicillium janczewskii Zaleski & 18 & 2 & 14 & & 24 & 13 & 5 & 76 \\
\hline Penicillium jensenii Zaleski & & & 1 & & & & 4 & 5 \\
\hline Penicillium minioluteum Dierckx & & & & & & 2 & & 2 \\
\hline Penicillium vinaceum Gilman et Abbott & 8 & & & & & & & 8 \\
\hline Penicillium waksmanii Zaleski & 7 & 1 & & & & & 1 & 9 \\
\hline Trichoderma aureoviride Rifai & & 3 & & 1 & 5 & & & 9 \\
\hline Trichoderma koningii Oudem. & & & & & & & & 2 \\
\hline Trichoderma viride Pers. & & & & & & & & \\
\hline Simplicillium lamellicola (F.E.V. Sm.) W. Gams & & & 3 & 1 & & & & 4 \\
\hline $\begin{array}{l}\text { Micromucor ramannianus var. ramannianus } \\
\text { (A. Möller) Arx }\end{array}$ & & & & 5 & & 5 \\
\hline Total: & & & & & & & & \\
\hline
\end{tabular}

Table 3

Similarities of soil fungi communities coming from compartment in Zielonka Experimental Forest District (W Poland)

\begin{tabular}{|c|c|c|c|c|c|c|}
\hline & $142 \mathrm{~d}$ & $85 \mathrm{c}$ & $64 \mathrm{c}$ & $47 \mathrm{k}$ & $43 \mathrm{f}$ & $35 \mathrm{~b}$ \\
\hline $5 \mathrm{a}$ & $28 \%$ & $14 \%$ & $20 \%$ & $24 \%$ & $17 \%$ & $18 \%$ \\
\hline $35 \mathrm{~b}$ & $24 \%$ & $29 \%$ & $60 \%$ & $27 \%$ & $19 \%$ & \\
\hline $43 \mathrm{f}$ & $22 \%$ & $21 \%$ & $21 \%$ & $11 \%$ & & \\
\hline $47 \mathrm{k}$ & $16 \%$ & $10 \%$ & $31 \%$ & & & \\
\hline $64 \mathrm{c}$ & $19 \%$ & $25 \%$ & & & & \\
\hline $85 \mathrm{c}$ & $19 \%$ & & & & & \\
\hline
\end{tabular}

In order to determine the qualitative similarities of fungi associations, on seven analyzed areas, similarity cocfficients of associations were determined according to the formula of Marczewski-Steinhaus (Tab. 3). Similarity determined in this way shows only the fact of occurrence or absence of the given fungi, but it does not indicate their frequency. 


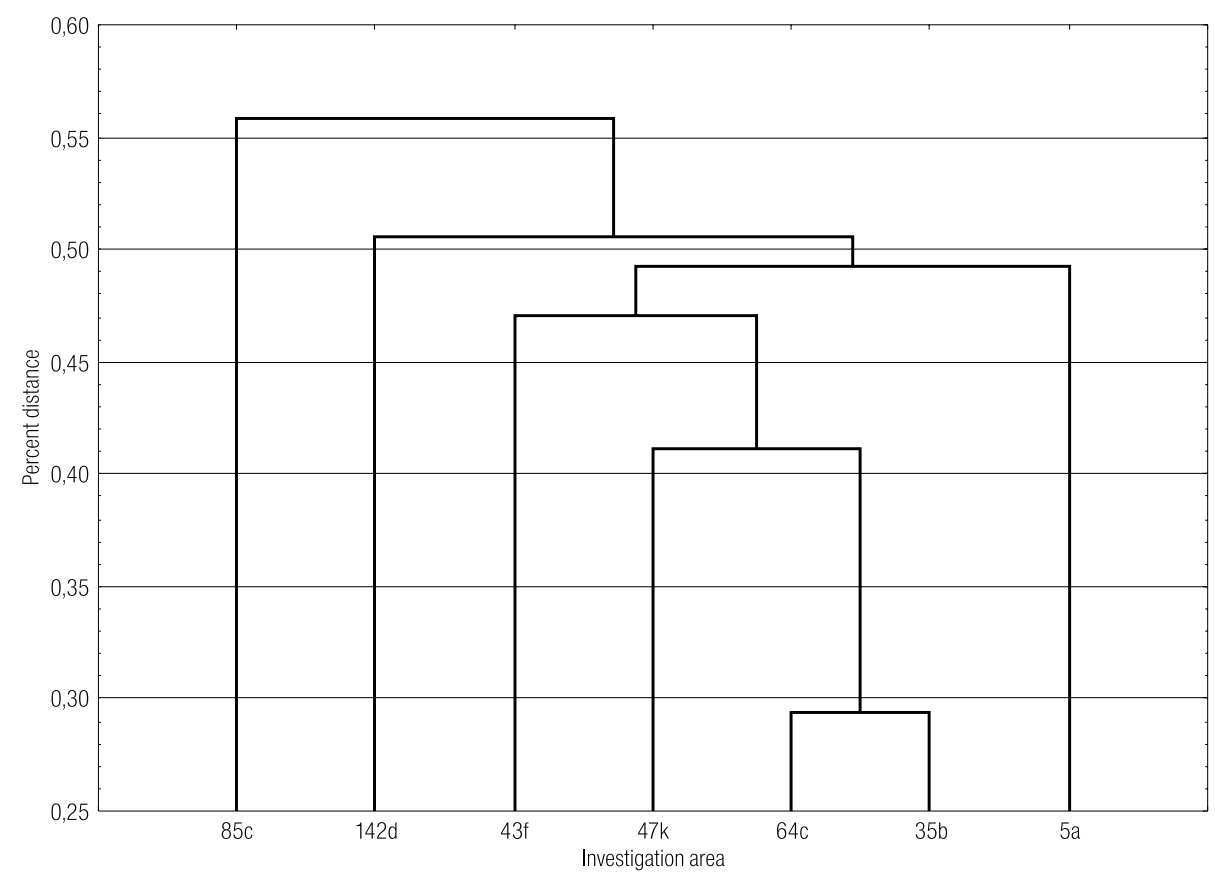

Fig. 1. Percentage distance between soil fungi community coming from compartment in Zielonka Experimental Forest District.

The greatest similarity. As height as $60 \%$ occurred in case of soil fungi communities from sites $64 \mathrm{c}$ and $35 \mathrm{~b}$. The least similarities were found between the communities of soil fungi from sites $47 \mathrm{k}$ and $43 \mathrm{f}$ amounting only to $11 \%$. Other soil fungi associations showed a similar qualitative similarity ranging between 14 and $31 \%$.

During the studies, the coefficient of the proportional distance between the associations was determined taking into consideration also the frequency of the given fungi species in the associations. The obtained coefficient values have been illustrated in the form of a dendrogram (Fig. 1). The greatest similarity occurred between the communities of soil fungi obtained from site $64 \mathrm{c}$ and $35 \mathrm{~b}$. The communities of soil fungi obtained from site $85 \mathrm{c}$ was the most different from the other ones.

\section{DISCUSSION}

On the studies areas where soil samples were taken for mycological analyses, observation were carried out referring to the monitoring of infections diseases of tree roots (Szewczyk 2005). On all studied areas, there occurred pine infestations by A. ostoyae. An exception was site $35 \mathrm{~b}$ where pine were attacked by $H$. annosum. In all studied areas there grew young planted trees, the soil was prepared in the same way (furrow ploughing) and the trees were in a similar age (9-13 years), however, they occupied different forest sites (Fresh coniferous forest, fresh mixed coniferous forest and Fresh mixed broadleaved forest). On the basis of a determined similarity of associations and the coefficient of proportional distance, one can conclude 
that there is no dependence between the qualitative and quantitative composition of soil fungi and the occurrence of Armillaria ostoyae and Heterobasidion annsoum, the forest sites type and the age of trees on the areas where samples were taken. All obtained isolates represented commonly occurring soil fungi. Some of them can have an effect on Armillaria spp. or Heterobasidion annosum. The most frequently occurring fungus type was Penicillium janczewski characterized by the production of enzymes which decompose cellular walls of wood making thereby an entrance for infection of Armillaria spp. (Bääth, Soderström 1980). Another type of fungus which may have an effect of Armillaria spp. is Trichoderma which trough antibiosis can limit the growth of rhizomorphs (Sh ow, Kile 2001). Fungi of Mortierella type do not play any significant role in soil metabolism, but they are able to decompose chitin Acremonium spp. Can be pathogens for humans and animals: the same refers also to Aspergillus spp. or Penicillium spp. causing sapergollotoxicoses and penicillotoxicoses.

\section{REFERENCES}

Bääth E., Söderström B.E. 1980. Degradation of macromolecules by microfungi isolated from different podzolic soil horizons. Can. J. Bot. 58: 422-425.

Dobosz M. 2001. Wspomagana komputerowo statystyczna analiza wyników badań. Akademicka Oficyna Wydawnicza Exit, Warszawa.

John son L.F., Mańka K. 1961. A modification of Warcup's soil-plate method for isolating soil fungi. Soil Sci. 92: 79-84.

Kowalsk i S. 1996. Biodiversity of soil fungi in converted stand of Pinus sylverstris L. as an indicator of environment degradation as the effect of industrial pollution. Phytopathol. Pol.12: 163-175.

Ma ń k a K., S a lm o n ow icz B. 1987. Udoskonalenie niektórych technik zmodyfikowanej metody płytek glebowych do izolowania grzybów z gleby z punktu widzenia mikologii fitopatologicznej. Rocz. Nauk Rol. Ser. E Ochr. Rośl. 17: 35-46.

Romaniszyn W. 1972. Uwagi krytyczne o definicji Sorensena i metodzie Renkonena obliczania współczynnika podobieństwa zbiorów. Wiad. Ekol. 18 (4): 375-380.

Szewczyk W. 2005. Monitoring Armillaria root rot in young (up to 20 yrs) Scots pine plantation in Zielonka Forest District. Acta Sci. Pol. Silv. Colendar. Rat. Ind. Lignar. 4 (2): 91-100.

Tyszkiewicz Z. 2001. Zbiorowiska grzybów glebowych i ich wpływ na kształtowanie się zdrowotności naturalnych odnowień dwóch różnych grądów. Zesz. Nauk. Politechniki Białostockiej. Inżynieria Środowiska 12. Białystok: 143-185.

Warcup J. 1950. The soil plate method for isolation of fungi from soil. Nature 166: 117-118.

\section{Zbiorowiska grzybów glebowych w młodych plantacjach sosny zwyczajnej}

atakowanej zgnilizną korzeni

\section{Streszczenie}

Celem badań było poznanie i porównanie zbiorowisk grzybów występujących w glebach leśnych wybranych siedlisk na terenie Nadleśnictwa Doświadczalnego Zielonka. W trakcie analiz mikologicznych gleby otrzymano ogółem 694 izolaty grzybów reprezentujące 33 gatunki. Najliczniej reprezentowanym gatunkiem był Penicillium daleae, który stanowił $75 \%$ wszystkich izolatów i wchodził w skład zbiorowisk ze wszystkich badanych wydzieleń. Drugim pod względem frekwencji był Penicillium janczewskii - jego udział w ogólnej liczbie izolatów wynosił $11 \%$. Wyznaczono współczynnik odległości procentowej między zbiorowiskami. Największe podobieństwo występuje między zbiorowiskami grzybów glebowych uzyskanych z powierzchni badawczych zlokalizowanych w wydzieleniu $64 \mathrm{c}$ i $35 \mathrm{~b}$. 